\title{
Georgian Ports and Establishing the Regional Status of Georgia
}

\author{
Tamar Dolbaia \\ Associate Professor, Department of Human Geography, Dean of Faculty of Social and Political Sciences, \\ IvaneJavakhishvili Tbilisi State University, Georgia
}

\begin{abstract}
The article deals with problems of Georgian sea port system formation in the context of the South Caucasus development taking into account regional socio-economic and security cooperation. Local ports are considered as a potent instrument for establishing and strengthening local cooperation with the wider view oftranscontinental ties using the Georgian strategic position as a safe outlet for the land-locked Central Asian countries into the global economic space.

Georgian Port Systems are one of the main factors of South Caucasus regional development. However, the region wide significance of Georgian ports will grow only after attracting additional cargo from the CA and perhaps China too.
\end{abstract}

Keywords: Georgia, Sea ports, Batumi, Poti, South Caucasus Region

\section{Introduction}

One of the main features of the distribution of production power of modern world is growing concentration of population and production in the seaside regions, caused bythe growing role of global distribution of labor, increasinguse of oceanic resources, use of economic advantages of marine transport, and orientation of the developed countries towards the import of raw materials.

Dissolution of the Soviet Union significantly changed geopolitical situation in Eurasia. South Caucasus was a "deadlock" of the Soviet Union and had less intensive foreign economic relations, but in a new reality this region started to play an important role in defining transport-communication network in Eurasia. Georgia has a desire to become a "sea gate" of South Caucasus, as it has distinctive strategic location among South Caucasus countries, thanks of its' connection to the Black Sea. Basic share of Armenia's and Azerbaijan's foreign economic relations are implemented through Georgian ports.

\section{Georgian ports as strategic assets}

In the Soviet period internal and external connections of Trans - Caucasus (the term used in the Russian Empire for the South Caucasus) and Central Asian republics with southern regions (Ukraine, southern Russia) of the Soviet Union and Europe were carried out through Georgian ports, but those connections were less intensive because of centralized economy and closed space of the socialist camp.

In 1990-s Trans - Caucasus countries gained independence and Georgian ports became important instruments of the currently called South Caucasus countries' social-economic development and its involvement in the global economic space.

Georgia has a two main sea ports - Batumi and Poti and Georgian governmentsupports building of another new sea port in Anakliabased on the conceptthat this additional port may play an important roleinfurthering a transit potential of the country ascertaining its economic development and the place and role of Georgia on the Great Silk Road. In 2016 Georgian government presented "Anaklia Deep water port project" on annual international investment forum in Dubai and received investment project of the year award.

Government of Georgia commits itself to create proper infrastructure for port development and to allocate land. Cost of the project is 2,5 billion USD. Presumable capacity of the port will be $100000 \mathrm{mln}$ tons, but it will start to operate from $7 \mathrm{mln}$ tons in three years' time after start of operation. 3400 people will be employed; the number will reach 6400 after the port becomes fully operative. It is a deep water port, depth of dock is 18-20,5 meters, which is deeper than that of Batumi and Poti, correspondingly: 12 and 8.5 meters, thus it will be possible to receive Mothervessels and Panamax type of ships. The port will receive ships with deadweight from 50 to 150 
000 tons, whose movement in ports of Batumi and Poti is problematic. Land area of the port is 400 ha and of FEZ - 600 ha.

It is claimed that the port will encourage development of the region and the country, will deepen tradeeconomic relations between Europe and Asia, as well as reduce time of transportation from China to Europe by 2 weeks.

Turnover of Anaklia port will surpass that of Batumi, Poti and Kulevi, but it will be difficult for the management to make the port fully loaded, because statistics of Georgian ports' turnover is not enviable. In 2015 turnover of Georgian ports decreased by $2.1 \mathrm{mln}$ tons - from $21,3 \mathrm{mln}$ to $19,2 \mathrm{mln}$. Particularly, turnover of Poti fell from 8.6 to $6,8 \mathrm{mln}$ tons and turnover of Batumi decreased from 6,3 to 5,7 tons per year.

Turnover of Supsa sea terminal in 2015 was $4.2 \mathrm{mln}$ tons, almost the same as in previous years, while turnover of Kulevi terminal increased by $2,5 \mathrm{mln}$ tons.

Capacity of Georgian ports are only half utilized and if this trend continues in the future, Anaklia port will become another unprofitable port in the country.

The port construction area borders the Kolkheti national park's marshlands, which is protected by UN Ramsar convention. On these unique marshlands the biggest migration route of birds is passing. Over 200 species of birds reside in the park. Area of the park already shrink by 843 ha, when the road connecting Poti and Anaklia was constructed, which goes through the middle of the park. Kolkheti national park also borders Kulevi oil terminal, and the sea channel and the railway going to the terminal are encompassing areas that are of vital importance for migrating birds, sturgeons and dolphins. During functioning of the port and the oil terminal it is essential to strengthen control over the environment.

Kulevi terminal has created ecological problems and in these uncertain geopolitical conditions we need to think about whether it will be justified to carry out another ecologically suspicious projectby Anaklia sea port.

To eradicate confrontation between port and touristic functions, it is necessary to make coastal line zoning and distinctly divide them. It will also support Georgian Black Sea coastline ecological security.

Kulevi oil terminal came into operation in 2008, management is conducted by Azerbaijan. Reservoir capacity - $320000 \mathrm{~m}^{3}$, capacity - $10 \mathrm{mln}$ tons of petroleum products, among them: $3 \mathrm{mln}$ tons of oil, $3 \mathrm{mln}$ tons of diesel, $4 \mathrm{mln}$ tons of fuel oil. The port can simultaneously process 180 carriages/cisterns. Seabed was deepened for servicing large tonnage tankers and now the port can receive tankers with tonnage of more than 100000 tons. Chemical cargo handling complex was built in 2012.

Batumi oil terminal - is a strategic oil transport asset in the Black Sea for Kazakhstan. Terminal is collecting cargo from Kazakhstan, Azerbaijan, and Turkmenistan. Area of the terminal is 90 ha, it has 5 reservoir parks, can handle 22 types of oil and petroleum products. Capacity is $15 \mathrm{mln}$ tons per year. It is specialized in processing of crude oil. It can handle 194 carriages/cisternssimultaneously and 770 carriages/cisternsper day. At present, Kazakhstan suspended functioning of the terminal.

Carrying capacity of Batumi dry bulk terminal is $15 \mathrm{mln}$ tons per year, while the turnover in 2000-2015 is shown on the table:

TABLE: \#1. Source Ministry of Economy Georgia

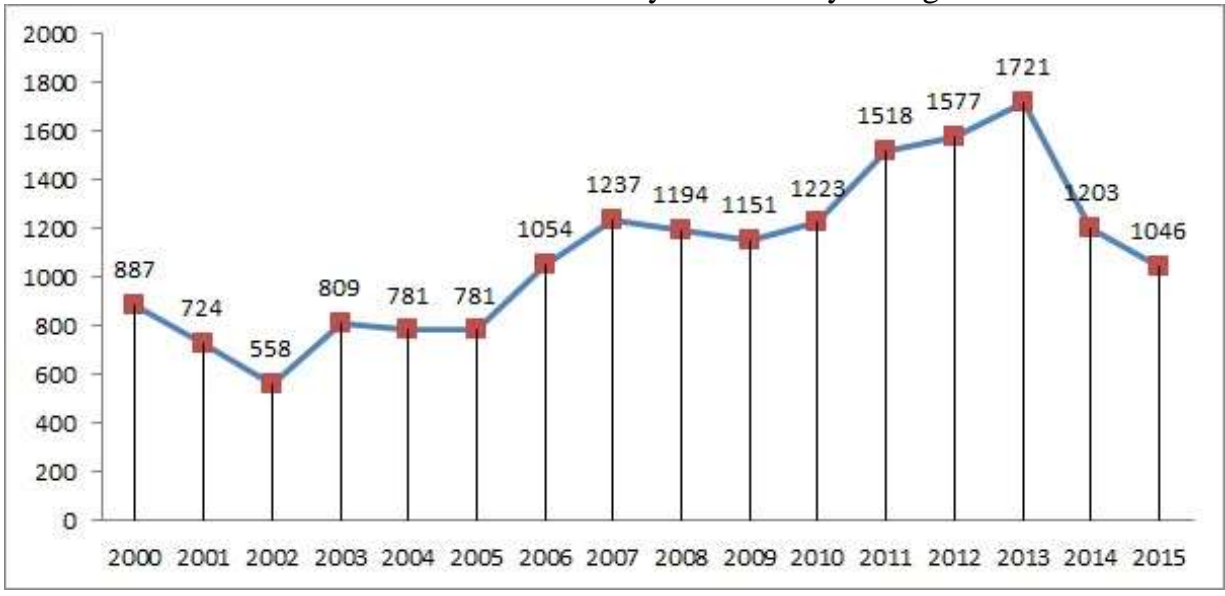


Batumi port, after Kazakhstan closed the oil terminal, is less valid for transferring dry bulk, because it has poor accessibility from the land and cannot compete with Poti and in the future with Anaklia ports. That's why it is better for Batumi port if it becomes travelling and cruise terminal in the Black Sea Basin, being situated in the center of the tourist zone.

Poti port was acquired by "APM terminals" and $70 \mathrm{mln}$ worth investment was brought. In 2013 the organization built container terminal, by 2018, 2 deep water, 16 meters deep docks will be built. Capacity will be $1 \mathrm{mln}$ TEU, and it will receive ships with 9000 TEU. Annual turnover or Poti mega port will be 50 mln tons and 2 mln TEU containers. It will be possible for mother vessels to enter, but in this case, Turkey's interests must be considered, it is unknown whether Turkey will admit in Bosporus strait the high tonnage ships and overload the strait.

Poti port is making transit in several directions: in Azerbaijan and Russia; in Turkmenistan, Afghanistan, Tajikistan, Uzbekistan via Baku-Turkmenbashi ferry; and in Kyrgyzstan, Kazakhstan, Uzbekistan via BakuAktau ferry. There are constant delays on both ferries, which significantly increases transit time from Poti port.

TABLE: \#2. Developed by author

\section{Key Transportation Figures of Georgia Handled Cargo (Tons mIn)}

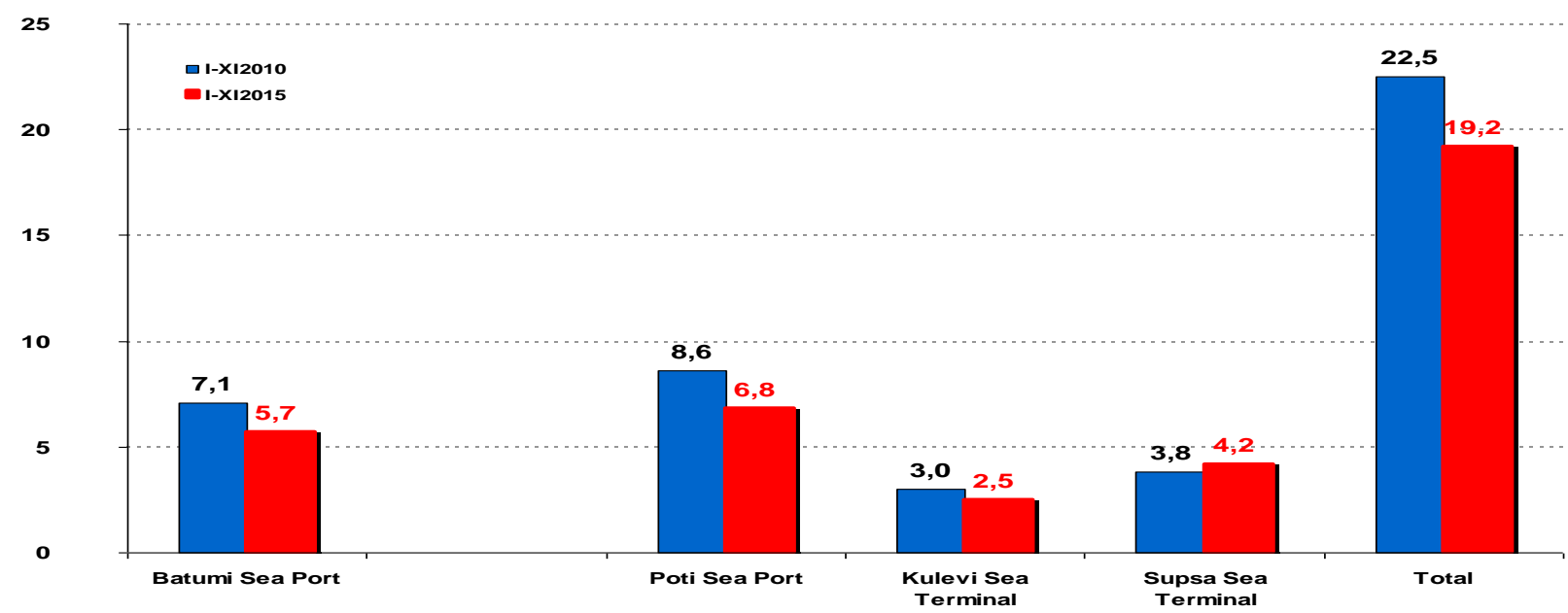

In Georgian ports $84 \%$ (2014) of processed transit cargo comes from Central Asia, Azerbaijan and Armenia.

From Poti port the following goods are transferred to Azerbaijan: bauxites, cereals, clinker from Turkey and Israel, clay, aluminum, quartz from Bulgaria and Ukraine, steel from Turkey, cars and equipment's from Belarus, Ukraine, Bulgaria, Moldova, Germany, Latvia and other countries; to Armenia- fuel, machines from Ukraine, Bulgaria, Russia. To both countries- tropical fruits, chicken, military cargo from Ukraine, Brazil, USA and others (report of port administration, 2014).

In Batumi port's turnover export-transit cargoes are: oil - from Azerbaijan, scrap-iron from Armenia, export-transit cargo of Central Asia are now passing through Russia. Import-transit cargo is intended for Azerbaijan, Armenia and Central Asia (report of port administration, 2014). 
TABLE: \#3. Turnover of Poti and Batumi ports, thousand tones (1984-2015), developed by author

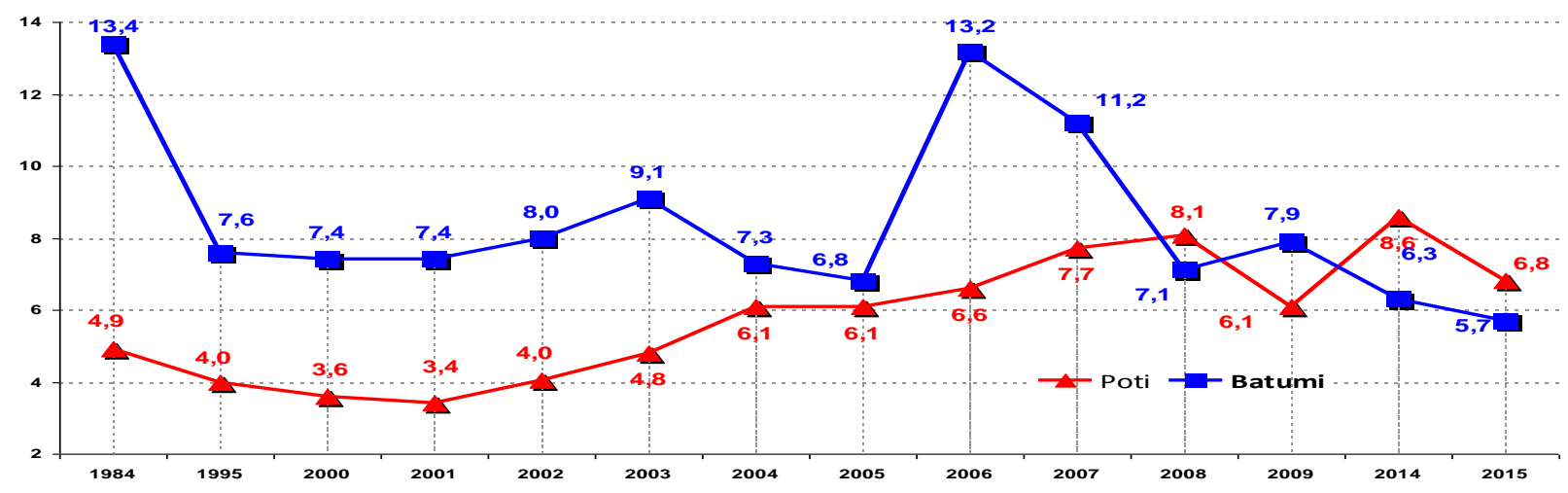

The following countries have the biggest share in import: Ukraine, Turkey, Greece, Russia, Italy, and Bulgaria. In export - Bulgaria, Italy, Turkey, Ukraine, Romania, Malta.

Because of Central Asia's landlocked location, countries of this region are searching for diversified directions of involvement in the world economic processes. The use of Georgian ports may be profitable for this region, both politically and economically, because it makes them less dependent on Russia.

One of the main instruments in port development is considered to be Free Economic Zone, which is of primary interest for Georgia. Taking into account the liberal legislation of Georgia, it is rather uncertain what benefits could the state and business get from the Poti Free Industrial Zone (FIZ). If the FIZ is able to develop port systems, provide import of raw materials and manufactured products for the whole South Caucasus, then it will have better perspectives for development.

\section{Conclusions}

Two forms of territorial organization of coastline - (a) port-industrial systems and (b) FEZ - are developing rapidly and gaining more importance due to the deepening of international distribution of labor in modern global space, increase of use of oceanic resources, using economic advantages of marine transport and orientation on imported raw material in industrially developed countries.

For Georgia, which is a peripheral part of Europe, creation and development of efficient port system is necessary for involvement in international trade and development of export oriented sectors of economy. Consequently it is necessary to elaborate state policy considering international experience.

Georgian ports have political, economic and social importance for country's security, economic development, involvement in the global space, employment and increasing of living standards of population. Future of Georgia's port systems depends on overcoming of the current political-economic crisis and international political development trends.

Georgian government's attitude towards its ports is not systemic and only spontaneous activities could be observed. Today Georgian government does not have any maritime policy. The only policy applied to ports is selling them out. By selling ports, Georgia loses control over development and integration into the global economic space.

TheEU actively attempts to promote policy of social-economic development of regions by developing regional transport infrastructure, the basis of which are considered to be sea ports.

Georgian ports were not affected as yet by the EU policies in the region. The EU has not developed any program to support Georgian ports, except for transnational project TRACECA, which was a political project to diversify international transport corridors from Russia and it did not bring economic benefits for participating 
countries. We hope that by entry into force of EU-Georgia Association Agreement (2014), the interest of EU towards Georgian ports will rise and Georgia will strengthen its positions in South Caucasus region, which will promoteregional cooperation, security and sustainable development.

Export-import and transit are important in structure of cargo flow for Batumi and Poti, since Georgia's internal market capacity is not enough to sufficiently load them, hence they also operate on treatment of South Caucasus and Central Asia's regional cargo. Development of transit functions is a guarantee of involvement in global economy. The world community also supports development of this function.

Trans Caspian international transport route project is very interesting, it is being considered among Georgia, Kazakhstan and Azerbaijan. Consortium ensures cargo flow from Chinese ports to Batumi and from there to Turkey and Europe. Turkey is interested in attracting cargo through land route and in Europe-Caucasus-Asia transport corridor the railway transit route is being developed; its new line is Baku-Tbilisi-Kars new railway section, which is connected to Istanbul-Ankara railway, which goes to Europe through Marmarai Tunnel. By this international project, cargo from China, Kazakhstan, Azerbaijan, Turkey will go to Europe.

Because of this transit railway corridor, Georgia's cargo flows will be split and part of them will be transferred to new direction, which will decrease turnover of Georgian ports, as of today by at least 2,5-3 mln tons. Because of this project not only Georgian port's revenue, but revenue of railway and transport companies will decrease.

China has already begun testing transfer cargo to Teheran via railway, which was impossible during US sanctions and now it is strong alternative to Trans Caspian route.

For years, government was determined to turn Georgia into the transport corridor, part of Great Silk Road. The basis for this was the isolation of Iran due to US sanctions, which made problematic transit of cargo from Central Asia through Iran. Now, despite the lifting of sanctions from Iran, Government of Georgia still considers possibility of construction of Anaklia port, as an important strategic part of Great Silk Road.

Today, actions of Georgian government depends more on geopolitical, rather than economic factors.

Hence, Georgian Port Systems are one of the main factors of South Caucasus regional development.

\section{References}

[1] Harding A. L. Seaports and people of Europe. Kissinger Publishing, 2007.

[2] Ismailov E.\&Papava V. The Central Caucasus. Problems of geopolitical economy. Nova Science Publishers, New York, 2008.

[3] Keeling D.J. Transportation geography new regional mobility's. Progress in Human Geography, 2008.http://phg.sagepub.com

[4] Dolbaia T. World experience of Free Economic zones and Georgia. Proceedings of conference materials. Tbilisi,2010.(In Georgian).

[5] http://www.geostat.ge/?lang=geo

[6] http://www.batumiport.com/

[7] http://www.potiseaport.com/

[8] Review of Maritime Transport 2015; http://unctad.org/en/PublicationsLibrary/rmt2014_en.pdf

[9] http://greenalt.org/old/map/text/kulevi_oil_terminal/kulevi_oil_terminal.htm

[10] http://www.commersant.ge/?m=5\&news id=33012

[11] Port Reform Toolkit PPIAF, World Bank, 2nd Edition;http://ppp.worldbank.org/public-private-partnership/library/portreform-toolkit-ppiaf-world-bank-2nd-edition 